\title{
RIGHT CORONARY ARTERY ORIGINATING FROM THE LEFT CORONARY SINUS: A RARE CORONARY ARTERY ANOMALY
}

\author{
Cenk Conkbayir \\ Anomalous origin of the right coronary artery $(\mathrm{RCA})$ from the left coronary sinus is \\ a rare congenital anomaly. Here, we report a case of a 54-year-old symptomatic \\ woman who was admitted with a history of unstable angina pectoris, hypertension, \\ coronary arteriosclerosis, diabetes mellitus, hypercholesterolemia and previous \\ coronary bypass operation (CABG). Coronary angiography was performed and a \\ right coronary artery was discovered, which was seen to arise from the left \\ coronary sinus.
}

Russ J Cardiol 2014, 1 (105), Engl.: 56-57
Key words: right coronary anomaly, congenital.

Near East University, Cardiology Department, Nicosia (north), Cyprus.

Corresponding author. Cenk Conkbayir, Assist Prof Dr, Altan Kamil Str No 15 Ortakoy, Nicosia (north), Cyprus, Tel: +905338775042, e-mail: cenkconk@hotmail.com

Received September 03, 2013.

Revision received September 16, 2013.

Accepted September 23, 2013.

\section{ПРАВАЯ КОРОНАРНАЯ АРТЕРИЯ, ПРОИСХОДЯЩАЯ ИЗ ЛЕВОГО КОРОНАРНОГО СИНУСА: РЕДКАЯ АНОМАЛИЯ КОРОНАРНОЙ АРТЕРИИ}

\section{Cenk Conkbayir}

Аномальное отхождение правой коронарной артерии (RCA) из левого коронарного синуса - редкая врожденная аномалия. Здесь, мы сообщаем о случае 54-летней женщины, которая была госпитализирована с нестабильной стенокардией, гипертонией, коронарным атеросклерозом, сахарным диабетом, гиперхолестеринемией и предыдущими операциями аортокоронарного шунтирования (АКШ) в анамнезе. При коронарной ангиографии правой коро-

\section{Introduction}

The incidence of coronary artery anomalies has been reported to be between $0.2 \%$ to $1.3 \%$ in angiographic series and $0.3 \%$ in autopsy series [1]. Most anomalies are not of clinical significance. However, some anomalies are related to angina, dyspnoea, syncope, acute myocardial infarction and sudden death [2]. In spite of the fact that in the past, an anomalous origin of the RCA from the left sinus of Valsalva was considered a benign finding, it is now evident that this anomaly can be associated with atypical chest pain, myocardial ischemia, and sudden death [3].

Here, we present a 54-year-old woman with an anomalous right coronary artery which arose from the left coronary sinus. In addition, this woman had a previous history of having undergone a coronary artery bypass grafting operation due to multi-vessel disease 7 years ago.

\section{Case report}

A 54-year-old woman with a prior history of hypertension and hypercholesterolemia, myocardial infarction and CABG operation presented to our hospital. On admission, her blood pressure was 130/80 $\mathrm{mmHG}$, with a regular pulse rate of $73 / \mathrm{bpm}$. ECG showed normal sinus rhythm and negative $\mathrm{T}$ waves on V4-6. We performed coronary angiography due to the presence of unstable angina pectoris. Angiography demonstrated a normal left main coronary artery (LMCA), severe stenosis in the mid portion of the Left anterior descending artery (LAD), mild stenosis in proximal segment of the circumflex artery $(\mathrm{CX})$, and нарной артерии был обнаружено, что она восходит из левого коронарного синуса.

Российский кардиологический журнал 2014, 1 (105), Англ.: 56-57

Ключевые слова: правая коронарнаяй аномалия, врожденный.

the LIMA_LAD graft to be totally occluded, and a right coronary artery was discovered, which was observed to arise from the left coronary sinus, coursing to the right side of the heart (Fig. A, B, C).

\section{Discussion}

The incidence of coronary artery anomalies has been reported between $0.6 \%$ to $1.3 \%$ in angiographic series and $0.3 \%$ in autopsy series [4]. The inter-arterial course of the LCA, between the aortic root and the pulmonary artery trunk, correlates with a higher incidence of angina, syncope and sudden death [5]. The anomalous origin of LCA from the right sinus of Valsalva is not always associated with symptoms of angina pectoris. Other anatomical variants including a retro-aortic course of the anomalous LCA, a right ventricle-free wall course and a septal course, along the floor of the right ventricle, are considered benign [6]. In our case, a right coronary artery was discovered that was seen to have arisen from the left coronary sinus. The ideal imaging tool for the diagnosis and delineation of coronary artery anomalies is coronary angiography. Other imaging modalities include computed tomography, magnetic resonance imaging and transesophageal echocardiography. In our case, at first, we could not identify the right coronary artery and hence, we performed aortography. We realized that the right coronary artery was originating from the left coronary sinus. Then, we performed selective angiography and demonstrated the origin of the RCA from the upper portion of the left coronary sinus. Anomalous coro- 

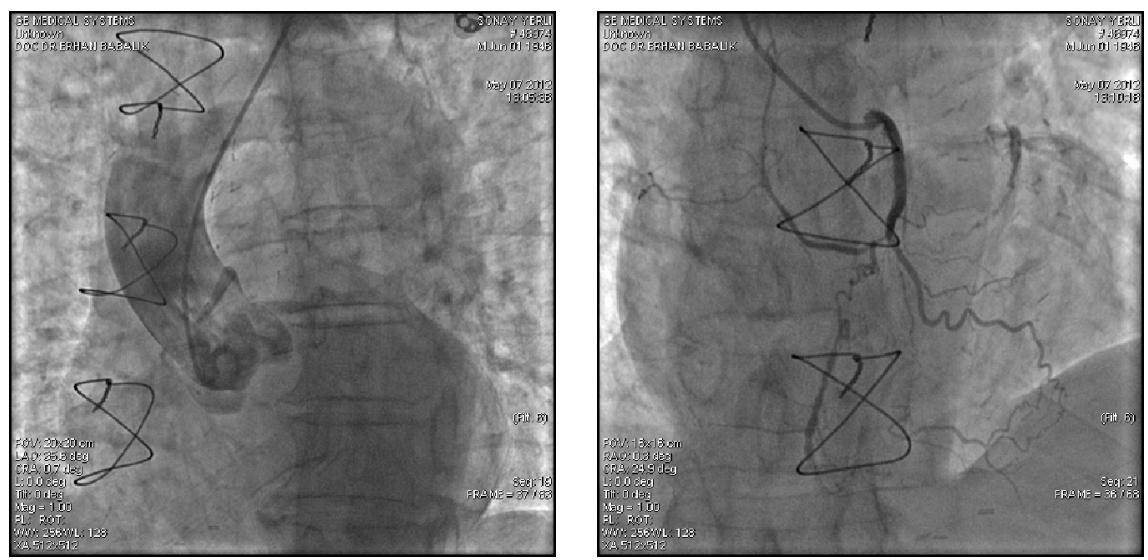

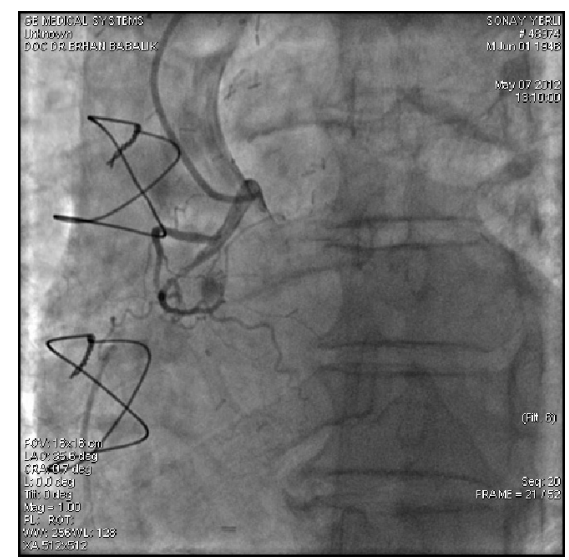

Figure 1

nary arteries do not appear to be associated with an increased risk of development of coronary atherosclerosis, but some patients with anomalous coronary arteries have symptoms of angina pectoris due to atherosclerosis [7]. Recently another case reported with anomalous origin of

\section{References}

1. Zhang LJ, Yang GF, Huang W, et al. Incidence of anomalous origin of coronary artery in 1879 Chinese adults on dual-source CT angiography. Neth Heart J 2010; 18: 466-70.

2. Sato $Y$, Inoue $F$, Kunimasa $T$, et al. Diagnosis of anomalous origin of the right coronary artery using multislice computed tomography: evaluation of possible causes of myocardial ischemia. Heart Vessels 2005; 20: 298-300.

3. Beique F, Tran HDQ, Ma F, et al. Anomalous Right Coronary Artery Originating From the Left Sinus of Valsalva- Case Conference. Journal of Cardiothoracic and Vascular Anesthesia, 2004;18, 6: 788-98.

4. Vincelj J, Todorović $\mathrm{N}$, Marusić $\mathrm{P}$, et al. Anomalous origin of the left coronary artery from the right sinus of Valsalva in a 62-year-old woman with unstable angina pectoris: a case report. Int J Cardiol 2010; 142: 35-7. right coronary artery from the left coronary sinus which resulted with sudden death and successful surgical reimplantation [8]. Aortography and selective coronary angiography should both be well evaluated in patients with anomalies of the coronary artery.

5. Tejada JG, Hernandez F, Sanches I, et al. Stenting of anomalous left main coronary arter arising from the right sinus of Valsalva: a case report. Int J Cardiol 2007; 119: 266-7.

6. Dogan SM, Gursurer M, Aydin M, et al. Myocardial ischemia caused by a coronary anomaly left anterior descending coronary artery arising from right sinus of Valsalva. Int J Cardiol 2006; 112: e57-9.

7. Colak MC, Erdil N, Disli O, et al. Anomalous Origin of the Left Coronary Artery from the Right Coronary Sinus Ann Thorac Cardiovasc Surg Advance, April 27, 2012 doi: 10.5761/ atcs.cr.11.01788.

8. Munoz-Guijosa C, Permanyer E, Leta R. Anomalous origin of right coronary artery from the left coronary sinus: sudden death and successful surgical reimplantation. European Heart Journal. doi:10.1093/eurheartj/ehr386. 14.10.201. 